\title{
Research Progress of Drug Treatment in Novel Coronavirus Pneumonia
}

\author{
Junqiang Yan, ${ }^{1,3}$ Anran Liu, ${ }^{1}$ Jiarui Huang, ${ }^{1}$ Jiannan Wu, ${ }^{1}$ and Hua Fan ${ }^{2}$
}

Received 20 March 2020; accepted 9 April 2020; published online 13 May 2020

Abstract. As of March 10, 2020, more than 100,000 novel coronavirus pneumonia cases
have been confirmed globally. With the continuous spread of the new coronavirus pneumonia
epidemic in even the world, prevention and treatment of the disease have become urgent
tasks. The drugs currently being developed are not adequate to deal with this critical
situation. In addition to being controlled through effective isolation, we need a rapid
response from the healthcare and biotechnology industries to accelerate drug treatment
research. By reviewing the currently available literature published at home and abroad, we
summarize the current research progress of drug treatment during the epidemic period. At
present, the drugs that can be used for treatment mainly include antiviral drugs, antimalarials,
glucocorticoids, plasma therapy, biological agents, and traditional Chinese medicine. The
effectiveness and safety of drug therapy need to be confirmed by more clinical studies.

KEY WORDS: novel coronavirus (2019-nCoV); pneumonia; drug therapy; research progress.

\section{INTRODUCTION}

On December 31, 2019, an unknown outbreak spread from Wuhan City, Hubei Province, China, and spread rapidly worldwide (1). The main clinical symptoms of this unexplained pneumonia are similar to severe acute respiratory syndrome (SARS) and Middle East respiratory syndrome (MERS), which can quickly develop from mild fever, fatigue, and dyspnea to severe pneumonia. Starting from the management experience of the SARS epidemic, China has rapidly carried out comprehensive prevention and control. On January 7, 2020, China officials officially announced that it would temporarily name the unexplained pathogen in Wuhan as 2019-novel coronavirus (nCoV) (2,3). The confirmed cases reported from outside China support human-to-human transmission $(4,5)$, which indicates that the outbreak is difficult to control (6,7). After two meetings on January 30, 2020 (January 22 and January 23, respectively), the World Health Organization regarded the outbreak of the 2019-nCoV as a public health emergency $(8,9)$. Although the development of vaccines has long-term prevention and control effects, rapid identification of drug treatment during the epidemic is the key to responding to the outbreak (10), and there is no clear treatment method at present (11). Studies have found that

\footnotetext{
${ }^{1}$ Molecular Biology Laboratory, The First Affiliated Hospital, College of Clinical Medicine of Henan University of Science and Technology, Luoyang, 471003, People's Republic of China.

${ }^{2}$ Department of Pharmacy, The First Affiliated Hospital, College of Clinical Medicine of Henan University of Science and Technology, Luoyang, 471003, People's Republic of China.

${ }^{3}$ To whom correspondence should be addressed. (e-mail: yanjq20062007@126.com)
}

2019-nCoV is a single-stranded RNA beta coronavirus similar to SARS and MERS (12), so current treatment is mainly based on the treatment experience of these two diseases (13) and further development of new targeted drugs. Currently, the drugs studied for the treatment of 2019-nCoV mainly include antivirals, antimalarials, glucocorticoids, plasma therapy, biological agents, and traditional Chinese medicine, among which lopinavir/ritonavir, ribavirin, remdesivir, chloroquine phosphate, and interferon are the main drugs. Here, we systematically review the current research that can be used in the treatment of 2019-nCoV, providing a theoretical basis for the next step of treatment and prevention.

\section{ANTIVIRAL THERAPY}

\section{Protease Inhibitor}

Disulfiram, as a protease inhibitor, is mainly represented by lopinavir and ritonavir, which have been proved to have inhibitory effects on SARS and MERS (14). Chinese studies have found that the combined use of lopinavir and ritonavir has a more obvious inhibitory effect on coronavirus during SARS (15). It is considered that the half-life of lopinavir can be increased by inhibiting cytochrome P450, thereby enhancing the antiviral effect. Lopinavir/ritonavir is a known antiretroviral drug targeting the human immunodeficiency virus (HIV), which is being evaluated for anti-2019-nCoV treatment (16). A randomized controlled clinical study of the effect of 2019-nCoV cases (ChiCTR2000029308) is also underway $(17,18)$. At present, the National Health Council has recommended the use of lopinavir and ritonavir as antivirus regimens for 2019-nCoV-related pneumonia. The latest recommended dose is listed in our table (19). 


\section{Nucleoside Analogues}

Favipiravir and ribavirin are representatives of nucleoside analogues and have broad-spectrum antiviral effects. Theoretically, favipiravir and ribavirin have certain antivirus effects, while in vitro experiments have proved that ribavirin has little antivirus effects (20). However, their combined effect cannot be ignored. For example, favipiravir combined with oseltamivir is better than application of oseltamivir in severe influenza (21). Ribavirin combined with lopinavir/ ritonavir seems to improve the clinical efficacy of SARS (22). It has been used for experimental treatment of 2019-nCoV.

\section{Experimental Nucleoside Analogues}

Remdesivir (GS-5734), a new nucleoside analogue, has been shown to be a potential broad-spectrum anticoronavirus drug $(23,24)$. However, unlike the approved nucleotide analogues, experimental results confirmed that they had a stronger effect on both human infection coronavirus and various bat-derived coronavirus, significantly inhibiting virus replication in human primary cell culture (25). A recent cell experimental study indicated that remdesivir could inhibit 2019-nCoV in vitro infections (26). It is considered that remdesivir can effectively inhibit respiratory virus replication and improve virus-infected lung tissues (23). Here is a report on the cure of an American patient infected with 2019-nCoV after remdesivir (27). Theoretically, remdesivir is currently the most promising drug for the treatment of 2019-nCoV and has relatively complete data on human pharmacokinetics and safety (28). More relevant clinical randomized controlled studies have been registered (mild-to-moderate 2019-nCoV: NCT04252664; severe 2019-nCoV: NCT04257656) and are expected to be completed within the next 2 months.

\section{Neuraminidase Inhibitor Oseltamivir}

Neuraminidase inhibitors (NAI), such as oral oseltamivir, inhaled zanamivir, and intravenous peramivir, are recommended as antiviral therapy for influenza (29). Studies have shown that neuraminidase inhibitors have been used to control MERS-CoV infection (30). According to empirical treatment, clinical used oseltamivir is widely to treat confirmed or suspected cases of 2019-nCoV in hospitals in China. And the research mentioned above shows that oseltamivir combined with fapilavir is more effective in treating severe influenza (21).

\section{Membrane Fusion Inhibitor}

Abidol, as a non-nucleoside drug, is a membrane fusion inhibitor with the activity of broad-spectrum antiviral drugs (31). It is more commonly called arbidol, as a membrane inhibitor, that blocks viral replication by inhibiting the fusion of influenza virus lipid membranes with host cells (32). Research considerations are mainly to prevent hemagglutinin (HA), a protein on the surface of influenza virus, which mediates membrane fusion, thereby inhibiting virus attachment to host cells $(32,33)$. Recent studies have shown that abidol can be used for the treatment of 2019-nCoV (19). Currently, a randomized multicenter controlled clinical study of abidol for 2019-nCoV (ChiCTR2000029573) has been initiated in China.

\section{ANTIMALARIAL DRUGS}

A multicenter clinical trial of chloroquine phosphate for treating the 2019-nCoV-associated pneumonia is underway in China, according to a press conference held by the State Council of China on February 17, 2020. Soon, chloroquine or hydroxychloroquine was tested in hospitals of Beijing, Shanghai, Wuhan, and other places for the treatment of 2019-nCoV-associated pneumonia (34). Chloroquine, as a known antimalarial drug, can inhibit the production and release of inflammatory factors in viral diseases and has antiviral effects on many diseases including HIV-1, hepatitis $\mathrm{B}$, and HCoV-229E (35). Recent studies have shown that chloroquine can inhibit 2019-nCoV by increasing the endosome $\mathrm{pH}$ required for viral cell fusion (26), and its antiviral and antiinflammatory activity considerations are also involved (36). A related open trial (ChiCTR2000029609) is ongoing.

\section{GLUCOCORTICOID}

A recent article published did not recommend glucocorticoids for 2019-nCoV patients (37). And study also opposes the widespread use of corticosteroids according to the latest expert consensus (38). However, there is also research evidence that low-dose corticosteroids can be used appropriately in subgroups such as severe patients to improve the survival advantage of patients $(39,40)$. Study suggested that low-to-moderate short-term corticosteroids can be used in severe patients with 2019-nCoV (41). Therefore, the current glucocorticoid treatment of 2019-nCoV-related pneumonia is still controversial. At present, it is only recommended to try intravenous methylprednisolone for 3-5 days, and it is not suitable for long-term use $(42,43)$.

\section{PLASMA THERAPY}

Previous research has shown that convalescent plasma can produce polyclonal antibodies to neutralize the virus (44), which can reduce the mortality of patients with viral infection (45). Therefore, cured patients can donate plasma for treatment (46) and research (47). And the Chinese Academy of Sciences research found that the 2019-nCoV virus isolated from the bronchoalveolar lavage fluid of severe patients could be neutralized by the serum of several patients. However, due to the timing of the recovery period, plasma may have lower antibody titers (48) and even other disease infections may occur. Therefore, the collection of plasma is very important; it needs to be at the right time and to ensure its safety. Due to the rapid outbreak and virus variability, plasma treatment has become relatively unsatisfactory (49).

\section{BIOLOGICAL AGENTS}

\section{Monoclonal Antibody}

Regarding monoclonal antibodies, some studies have suggested that monoclonal antibody CR3022 for SARS treatment may be used to treat 2019-nCoV (50). Monoclonal 
Table I. The Drugs of 2019-nCoV-Related Pneumonia

\begin{tabular}{|c|c|c|c|}
\hline Drug type & Representative drug & Reference dose & Reference \\
\hline \multicolumn{4}{|l|}{ Antiviral therapy } \\
\hline Protease inhibitor & Lopinavir & $400 \mathrm{mg} \mathrm{q} 12 \mathrm{~h}$, po, 14 days & $(15,19)$ \\
\hline & Ritonavir & 100 mg q12h, po, 14 days & $(15,19)$ \\
\hline Nucleoside analogues & Favipiravir & $1800 \mathrm{mg} / 800 \mathrm{mg}$ & $(20,21)$ \\
\hline & Ribavirin & $500 \mathrm{mg}$ tid, i.v. gtt, 14 day & $(58)$ \\
\hline Experimental nucleoside analogues & Remdesivir & $10 \mathrm{mg} / \mathrm{kg}$ & $(26,27)$ \\
\hline Neuraminidase inhibitor oseltamivir & Oseltamivir & $75 \mathrm{mg}$ bid, 10 days & $(21,29)$ \\
\hline Membrane fusion inhibitor & Arbidol & $0.2 \mathrm{~g}, \mathrm{tid}, \mathrm{po}, 2$ weeks & $(19,32)$ \\
\hline \multicolumn{4}{|l|}{ Antimalarial drugs } \\
\hline Chloroquine & Chloroquine phosphate & $500 \mathrm{mg}$ bid & $(34,35)$ \\
\hline \multicolumn{4}{|l|}{ Glucocorticoid } \\
\hline Corticosteroids & Methylprednisolone & $1-2 \mathrm{mg} / \mathrm{kg} /$ day, $3-5$ days, & $(57)$ \\
\hline \multicolumn{4}{|l|}{ Plasma therapy } \\
\hline Cured patients plasma & Convalescent plasma & no symptoms in 14 days, COVID-19 negative & $(46)$ \\
\hline \multicolumn{4}{|l|}{ Biological agents } \\
\hline Monoclonal antibody & CR3022 & 1 & $(50)$ \\
\hline Interferon & Interferon- $\alpha$ & $2-4 \mu \mathrm{g} / \mathrm{kg}$ bid, 5-7 days & $(57)$ \\
\hline ACE2-Fc & ACE2-Fc & 1 & $(60,61)$ \\
\hline \multicolumn{4}{|l|}{ Chinese traditional medicine } \\
\hline Heat-clearing and detoxicating drugs & SFJDC & $2.08 \mathrm{~g}, \mathrm{tid}$, po, 2 weeks & (19) \\
\hline
\end{tabular}

antibodies based on passive immunotherapy overcome many shortcomings of serum and intravenous immunoglobulin preparations and have been the focus of antiviral therapy. Previous studies have shown that monoclonal antibodies can remarkably improve the MERS-CoV infection (51). Research by Mark et al. shows that monoclonal antibodies REGN-EB3 and mAb114 can significantly reduce the mortality of patients with Ebola (28). Reviewing the recently research progress, it is suggested that monoclonal antibodies can be used for the treatment of 2019-nCoV (52). However, no relevant monoclonal antibodies have been successfully marketed yet (53). It is mainly based on the latest experiments that the CR3022 can effectively bind to the 2019-nCoV receptor-binding domain (50) that mainly targets the spike protein and inhibits the virus from attaching to the host cell, thereby preventing the virus from invading. Through this passive immunotherapy, it makes the treatment more targeted, and it is conducive to the development of vaccines (53).

\section{Interferon}

Studies have shown that the treatment of 2019-nCoV infection can improve survival by interferon (1). Interferon and ribavirin, these two antiviral drugs, are always used in combination for hepatitis $\mathrm{C}$ treatment. Studies show that ribavirin can enhance the antiviral effect of interferon through the mTOR (54) and EKR1/2 pathways (55). And trials involving it, such as the approved interferon plus ribavirin trial (ChiCTR2000029387), have begun. Using marmoset animal models, Chinese scholars found that interferon- $\beta$ combined with lopinavir/ritonavir had better efficacy to treat the MERS-CoV (56). New research shows that interferon- $\alpha$ nebulization, injection of interferon- $\alpha 2 b$ (57), and $\alpha$-interferon combined with lopinavir/ritonavir drugs (58) may be applicable to the current treatment of 2019-nCoV infection.

\section{ACE2-Fc}

Studies have shown that the entry receptor for 2019nCoV-infected lung cells may be angiotensin-converting enzyme II (ACE2) (2), so cells expressing ACE2 can serve as target cells (59). Moreover, studies have shown that the receptor mechanism about $2019-\mathrm{nCoV}$ is mainly based on the coronavirus spike (S) glycoprotein $(60,61)$. Current treatments can fuse the ACE2 into the immunoglobulin Fc domain to block virus entry and establish lasting immunity (62). This provides a new direction for the treatment of the 2019-nCoV.

\section{CHINESE TRADITIONAL MEDICINE}

Relevant research has used computer and biological processing to extract natural compounds with antiviral effect that have been verified by PubMed. These compounds were searched in the unique research database, found out 13 compounds, and identified more than 100 kinds of herbs. At last, 26 kinds of herbal plants, such as Bupleurum, Coptischinensis, Forsythia, and Glycyrrhizae, were selected out, which are highly likely to directly inhibit the 2019-nCoV (63). This method of promoting drug research through science and technology promotes the choice of clinical treatment. An example of combining traditional Chinese and western medicine shows that SFJDC can be used for the treatment of new coronary pneumonia (19). This drug is also recommended in the treatment on the disease (5th edition). Of course, the treatment principle is constantly being updated.

\section{CONCLUSION}

Current studies have shown that the drug treatment of 2019-nCoV-related pneumonia mainly includes antivirals, 
antimalarials, and interferon. The main representative drugs are lopinavir/ritonavir, ribavirin, remdesivir, interferon, and so on (Table I). More choices are being put into the research process, such as barretinib (64), imatinib (31), sunitinib, erlotinib (65), nitazoxanide (26), and other potential drugs, as well as fusion peptide (EK1) (66), HR2P (67), and other new peptides. And the development of vaccines is also a longterm goal. We need more clinical practice to test out more old drugs that can be used for treatment and, at the same time, search for new drugs with targeted and effective results.

\section{FUNDING INFORMATION}

This work was supported by the Natural Science Foundation of Henan Province (18230041033).

\section{COMPLIANCE WITH ETHICAL STANDARDS}

Competing Interests The authors declare that they have no competing interests.

\section{REFERENCES}

1. Huang C, Wang Y, Li X, Ren L, Zhao J, Hu Y, et al. Clinical features of patients infected with 2019 novel coronavirus in Wuhan, China. Lancet. 2020;395(10223):497-506. https:// doi.org/10.1016/s0140-6736(20)30183-5.

2. Zhou P, Yang XL, Wang XG, Hu B, Zhang L, Zhang W, et al. A pneumonia outbreak associated with a new coronavirus of probable bat origin. Nature. 2020;579:270-3. https://doi.org/ 10.1038/s41586-020-2012-7.

3. Zhu N, Zhang D, Wang W, Li X, Yang B, Song J, et al. A novel coronavirus from patients with pneumonia in China, 2019. N Engl J Med. 2020;382(8):727-33. https://doi.org/10.1056/ NEJMoa2001017.

4. Chan JF, Yuan S, Kok KH, To KK, Chu H, Yang J, et al. A familial cluster of pneumonia associated with the 2019 novel coronavirus indicating person-to-person transmission: a study of a family cluster. Lancet. 2020;395(10223):514-23. https://doi.org/ 10.1016/s0140-6736(20)30154-9.

5. Li Q, Guan X, Wu P, Wang X, Zhou L, Tong Y, et al. Early transmission dynamics in Wuhan, China, of novel coronavirusinfected pneumonia; 2020. https://doi.org/10.1056/ NEJMoa2001316.

6. Mahase E. China coronavirus: what do we know so far? BMJ. 2020;368:m308. https://doi.org/10.1136/bmj.m308.

7. Wu JT, Leung K, Leung GM. Nowcasting and forecasting the potential domestic and international spread of the 2019-nCoV outbreak originating in Wuhan, China: a modelling study. Lancet. 2020;395(10225):689-97. https://doi.org/10.1016/s01406736(20)30260-9.

8. Patel A, Jernigan DB. Initial public health response and interim clinical guidance for the 2019 novel coronavirus outbreak United States, December 31, 2019-February 4, 2020. MMWR Morb Mortal Wkly Rep. 2020;69(5):140-6. https://doi.org/ 10.15585/mmwr.mm6905e1.

9. Eurosurveillance Editorial T. Note from the editors: World Health Organization declares novel coronavirus (2019-nCoV) sixth public health emergency of international concern. Euro Surveill. 2020;25(5). https://doi.org/10.2807/15607917.ES.2020.25.5.200131e.
10. Lu H, Stratton CW, Tang YW. Outbreak of pneumonia of unknown etiology in Wuhan, China: the mystery and the miracle. 2020;92(4):401-2. https://doi.org/10.1002/jmv.25678.

11. $\mathrm{Lu} \mathrm{H}$. Drug treatment options for the 2019-new coronavirus (2019-nCoV). Biosci Trends. 2020;14:69-71. https://doi.org/ 10.5582/bst.2020.01020.

12. Morse JS, Lalonde T, Xu S, Liu WR. Learning from the past: possible urgent prevention and treatment options for severe acute respiratory infections caused by 2019-nCoV. 2020;21(5):730-8. https://doi.org/10.1002/cbic.202000047.

13. Li H, Wang YM, Xu JY, Cao B. Potential antiviral therapeutics for 2019 novel coronavirus. Zhonghua Jie He He Hu Xi Za Zhi. 2020;43(0):E002. https://doi.org/10.3760/cma.j.issn.10010939.2020.0002.

14. Zumla A, Chan JF, Azhar EI, Hui DS, Yuen KY. Coronaviruses - drug discovery and therapeutic options. Nat Rev Drug Discov. 2016;15(5):327-47. https://doi.org/10.1038/nrd.2015.37.

15. Chu CM, Cheng VC, Hung IF, Wong MM, Chan KH, Chan KS, et al. Role of lopinavir/ritonavir in the treatment of SARS: initial virological and clinical findings. Thorax. 2004;59(3):252-6. https://doi.org/10.1136/thorax.2003.012658.

16. Salata C, Calistri A, Parolin C, Palu G. Coronaviruses: a paradigm of new emerging zoonotic diseases. Pathog Dis. 2019;77(9). https://doi.org/10.1093/femspd/ftaa006.

17. Wang C, Horby PW, Hayden FG, Gao GF. A novel coronavirus outbreak of global health concern. Lancet. 2020;395(10223):470-3. https://doi.org/10.1016/s01406736(20)30185-9.

18. Cohen J. New coronavirus threat galvanizes scientists. Science (New York, NY). 2020;367(6477):492-3. https://doi.org/10.1126/ science.367.6477.492.

19. Wang Z, Chen X, Lu Y, Chen F, Zhang W. Clinical characteristics and therapeutic procedure for four cases with 2019 novel coronavirus pneumonia receiving combined Chinese and Western medicine treatment. Biosci Trends. 2020;14(1):64-8. https:// doi.org/10.5582/bst.2020.01030.

20. Smith EC, Blanc H, Surdel MC, Vignuzzi M, Denison MR. Coronaviruses lacking exoribonuclease activity are susceptible to lethal mutagenesis: evidence for proofreading and potential therapeutics. PLoS Pathog. 2013;9(8):e1003565. https://doi.org/ 10.1371/journal.ppat.1003565.

21. Wang Y, Fan G, Salam A, Horby P, Hayden FG, Chen C, et al. Comparative effectiveness of combined favipiravir and oseltamivir therapy versus oseltamivir monotherapy in critically ill patients with influenza virus infection. J Infect Dis. 2019;221:1688-98. https://doi.org/10.1093/infdis/jiz656.

22. Omrani AS, Saad MM, Baig K, Bahloul A, Abdul-Matin M, Alaidaroos AY, et al. Ribavirin and interferon alfa-2a for severe Middle East respiratory syndrome coronavirus infection: a retrospective cohort study. Lancet Infect Dis. 2014;14(11):1090-5. https://doi.org/10.1016/s14733099(14)70920-x.

23. Sheahan TP, Sims AC, Leist SR, Schafer A, Won J, Brown AJ, et al. Comparative therapeutic efficacy of remdesivir and combination lopinavir, ritonavir, and interferon beta against MERS-CoV. 2020;11(1):222. https://doi.org/10.1038/s41467-01913940-6.

24. Agostini ML, Andres EL, Sims AC, Graham RL, Sheahan TP, $\mathrm{Lu} \mathrm{X}$, et al. Coronavirus susceptibility to the antiviral remdesivir (GS-5734) is mediated by the viral polymerase and the proofreading exoribonuclease. mBio. 2018;9(2). https://doi.org/ 10.1128/mBio.00221-18.

25. Brown AJ, Won JJ, Graham RL, Dinnon KH, Sims AC, Feng $J Y$, et al. Broad spectrum antiviral remdesivir inhibits human endemic and zoonotic deltacoronaviruses with a highly divergent RNA dependent RNA polymerase. Antivir Res. 2019;169:104541. https://doi.org/10.1016/j.antiviral.2019.104541.

26. Wang M, Cao R, Zhang L, Yang X, Liu J, Xu M, et al. Remdesivir and chloroquine effectively inhibit the recently emerged novel coronavirus (2019-nCoV) in vitro. 2020;30(3):269-71. https://doi.org/10.1038/s41422-020-0282-0.

27. Holshue ML, DeBolt C, Lindquist S, Lofy KH, Wiesman J, Bruce H, et al. First case of 2019 novel coronavirus in the United States. N Engl J Med. 2020;382(10):929-36. https:// doi.org/10.1056/NEJMoa2001191. 
28. Mulangu S, Dodd LE, Davey RT Jr, Tshiani Mbaya O, Proschan M, Mukadi D, et al. A randomized, controlled trial of Ebola virus disease therapeutics. 2019;381(24):2293-303. https:// doi.org/10.1056/NEJMoa1910993.

29. Chow EJ, Doyle JD, Uyeki TM. Influenza virus-related critical illness: prevention, diagnosis, treatment. 2019;23(1):214. https:// doi.org/10.1186/s13054-019-2491-9.

30. Bleibtreu A, Jaureguiberry S, Houhou N, Boutolleau D, Guillot $\mathrm{H}$, Vallois D, et al. Clinical management of respiratory syndrome in patients hospitalized for suspected Middle East respiratory syndrome coronavirus infection in the Paris area from 2013 to 2016. BMC Infect Dis. 2018;18(1):331. https:// doi.org/10.1186/s12879-018-3223-5.

31. Coleman CM, Sisk JM, Mingo RM, Nelson EA, White JM, Frieman MB. Abelson kinase inhibitors are potent inhibitors of severe acute respiratory syndrome coronavirus and Middle East respiratory syndrome coronavirus fusion. J Virol. 2016;90(19):8924-33. https://doi.org/10.1128/jvi.01429-16.

32. Kadam RU, Wilson IA. Structural basis of influenza virus fusion inhibition by the antiviral drug Arbidol. Proc Natl Acad Sci U S A. 2017;114(2):206-14. https://doi.org/10.1073/pnas.1617020114.

33. Cihan-Ustundag G, Zopun M, Vanderlinden E, Ozkirimli E, Persoons L, Capan G, et al. Superior inhibition of influenza virus hemagglutinin-mediated fusion by indole-substituted spirothiazolidinones. Bioorg Med Chem. 2020;28(1):115130. https://doi.org/10.1016/j.bmc.2019.115130.

34. Cortegiani A, Ingoglia G, Ippolito M, Giarratano A, Einav S. A systematic review on the efficacy and safety of chloroquine for the treatment of COVID-19. J Crit Care. 2020. https://doi.org/ 10.1016/j.jcrc.2020.03.005.

35. Keyaerts E, Vijgen L, Maes P, Neyts J, Van Ranst M. In vitro inhibition of severe acute respiratory syndrome coronavirus by chloroquine. Biochem Biophys Res Commun. 2004;323(1):2648. https://doi.org/10.1016/j.bbrc.2004.08.085.

36. Gao J, Tian Z, Yang X. Breakthrough: Chloroquine phosphate has shown apparent efficacy in treatment of COVID-19 associated pneumonia in clinical studies. Biosci Trends. 2020;14:72-3. https://doi.org/10.5582/bst.2020.01047.

37. Russell CD, Millar JE, Baillie JK. Clinical evidence does not support corticosteroid treatment for 2019-nCoV lung injury. Lancet. 2020;395(10223):473-5. https://doi.org/10.1016/s01406736(20)30317-2.

38. Zhao JP, Hu Y, Du RH, Chen ZS, Jin Y, Zhou M, et al. Expert consensus on the use of corticosteroid in patients with 2019. $\mathrm{nCoV}$ pneumonia. Zhonghua Jie $\mathrm{He} \mathrm{He} \mathrm{Hu} \mathrm{Xi} \mathrm{Za} Z$ Zhi. 2020;43(0):E007. https://doi.org/10.3760/cma.j.issn.10010939.2020.0007.

39. Rhodes A, Evans LE, Alhazzani W, Levy MM, Antonelli M, Ferrer R, et al. Surviving sepsis campaign: international guidelines for management of sepsis and septic shock: 2016. Intensive Care Med. 2017;43(3):304-77. https://doi.org/10.1007/ s00134-017-4683-6.

40. Li H, Yang SG, Gu L, Zhang Y, Yan XX, Liang ZA, et al. Effect of low-to-moderate-dose corticosteroids on mortality of hospitalized adolescents and adults with influenza A(H1N1)pdm09 viral pneumonia. 2017;11(4):345-54. https://doi.org/10.1111/ irv. 12456.

41. Shang L, Zhao J, Hu Y, Du R, Cao B. On the use of corticosteroids for 2019-nCoV pneumonia. Lancet. 2020;395(10225):683-4. https://doi.org/10.1016/s01406736(20)30361-5.

42. Perlman S. Another decade, another coronavirus. N Engl J Med. 2020;382(8):760-2. https://doi.org/10.1056/NEJMe2001126.

43. Bajema KL, Oster AM, McGovern OL, Lindstrom S, Stenger MR, Anderson TC, et al. Persons evaluated for 2019 novel coronavirus - United States, January 2020. MMWR Morb Mortal Wkly Rep. 2020;69(6):166-70. https://doi.org/10.15585/ mmwr.mm6906e1.

44. Walker LM, Burton DR. Passive immunotherapy of viral infections: 'super-antibodies' enter the fray. Nat Rev Immunol. 2018;18(5):297-308. https://doi.org/10.1038/nri.2017.148.

45. Mair-Jenkins J, Saavedra-Campos M, Baillie JK, Cleary P, Khaw FM, Lim WS, et al. The effectiveness of convalescent plasma and hyperimmune immunoglobulin for the treatment of severe acute respiratory infections of viral etiology: a systematic review and exploratory meta-analysis. J Infect Dis. 2015;211(1):80-90. https://doi.org/10.1093/infdis/jiu396.

46. Tanne JH. Covid-19: FDA approves use of convalescent plasma to treat critically ill patients. BMJ. 2020;368:m1256. https:// doi.org/10.1136/bmj.m1256.

47. Mire CE, Geisbert JB, Agans KN, Thi EP, Lee AC, Fenton KA, et al. Passive immunotherapy: assessment of convalescent serum against Ebola virus Makona infection in nonhuman primates. J Infect Dis. 2016;214(suppl 3):S367-s74. https:/doi.org/10.1093/ infdis/jiw333.

48. van Griensven J, Edwards T, de Lamballerie X, Semple MG, Gallian P, Baize S, et al. Evaluation of convalescent plasma for Ebola virus disease in Guinea. N Engl J Med. 2016;374(1):3342. https://doi.org/10.1056/NEJMoa1511812.

49. Marano G, Vaglio S, Pupella S, Facco G, Catalano L, Liumbruno GM, et al. Convalescent plasma: new evidence for an old therapeutic tool? Blood Transfus. 2016;14(2):152-7. https://doi.org/10.2450/2015.0131-15.

50. Tian X, Li C, Huang A, Xia S, Lu S, Shi Z. Potent binding of 2019 novel coronavirus spike protein by a SARS coronavirusspecific human monoclonal antibody. 2020;9(1):382-5. https:// doi.org/10.1080/22221751.2020.1729069.

51. Johnson RF, Bagci U, Keith L, Tang X, Mollura DJ, Zeitlin L, et al. 3B11-N, a monoclonal antibody against MERS-CoV, reduces lung pathology in rhesus monkeys following intratracheal inoculation of MERS-CoV Jordan-n3/2012. Virology. 2016;490:49-58. https://doi.org/10.1016/j.virol.2016.01.004.

52. Jin Y, Lei C, Hu D, Dimitrov DS, Ying T. Human monoclonal antibodies as candidate therapeutics against emerging viruses. Front Med. 2017;11(4):462-70. https://doi.org/10.1007/s11684017-0596-6.

53. Shanmugaraj B, Siriwattananon K, Wangkanont K, Phoolcharoen W. Perspectives on monoclonal antibody therapy as potential therapeutic intervention for coronavirus disease-19 (COVID-19). Asian Pac J Allergy Immunol. 2020;38(1):10-8. https://doi.org/10.12932/ap-200220-0773.

54. Su WC, Liu WL, Cheng CW, Chou YB, Hung KH, Huang WH, et al. Ribavirin enhances interferon signaling via stimulation of mTOR and p53 activities. FEBS Lett. 2009;583(17):2793-8. https://doi.org/10.1016/j.febslet.2009.07.027.

55. Liu WL, Yang HC, Su WC, Wang CC, Chen HL, Wang HY, et al. Ribavirin enhances the action of interferon-alpha against hepatitis $\mathrm{C}$ virus by promoting the p53 activity through the ERK1/2 pathway. PLoS One. 2012;7(9):e43824. https://doi.org/ 10.1371/journal.pone.0043824.

56. Chan JF, Yao Y, Yeung ML, Deng W, Bao L, Jia L, et al. Treatment with lopinavir/ritonavir or interferon-beta1b improves outcome of MERS-CoV infection in a nonhuman primate model of common marmoset. J Infect Dis. 2015;212(12):1904-13. https://doi.org/10.1093/infdis/jiv392.

57. Shen K, Yang Y, Wang T, Zhao D, Jiang Y, Jin R, et al. Diagnosis, treatment, and prevention of 2019 novel coronavirus infection in children: experts' consensus statement. World J Pediatr. 2020. https://doi.org/10.1007/s12519-020-00343-7.

58. Lin L, Li TS. Interpretation of "Guidelines for the diagnosis and treatment of novel coronavirus (2019-nCoV) infection by the National Health Commission (Trial Version 5)". Zhonghua Yi Xue Za Zhi. 2020;100(0):E001. https://doi.org/10.3760/ cma.j.issn.0376-2491.2020.0001.

59. Xu H, Zhong L, Deng J, Peng J, Dan H, Zeng X, et al. High expression of ACE2 receptor of $2019-\mathrm{nCoV}$ on the epithelial cells of oral mucosa. Int J Oral Sci. 2020;12(1):8. https://doi.org/ 10.1038/s41368-020-0074-x.

60. Letko M, Marzi A. Functional assessment of cell entry and receptor usage for SARS-CoV-2 and other lineage B betacoronaviruses; 2020. https://doi.org/10.1038/s41564-0200688-y.

61. Wan Y, Shang J, Graham R, Baric RS, Li F. Receptor recognition by novel coronavirus from Wuhan: an analysis based on decade-long structural studies of SARS. J Virol. 2020;94. https://doi.org/10.1128/jvi.00127-20.

62. Kruse RL. Therapeutic strategies in an outbreak scenario to treat the novel coronavirus originating in Wuhan, China. F1000Research. 2020;9:72. https://doi.org/10.12688/ f1000research.22211.2. 
63. Zhang DH, Wu KL, Zhang X, Deng SQ, Peng B. In silico screening of Chinese herbal medicines with the potential to directly inhibit 2019 novel coronavirus. J Integr Med. 2020;18:152-8. https://doi.org/10.1016/j.joim.2020.02.005.

64. Richardson P, Griffin I, Tucker C, Smith D, Oechsle O, Phelan A, et al. Baricitinib as potential treatment for 2019-nCoV acute respiratory disease. Lancet. 2020;395(10223):e30-e1. https:// doi.org/10.1016/s0140-6736(20)30304-4.

65. Pu SY, Xiao F, Schor S, Bekerman E, Zanini F, Barouch-Bentov $\mathrm{R}$, et al. Feasibility and biological rationale of repurposing sunitinib and erlotinib for dengue treatment. Antivir Res. 2018;155:67-75. https://doi.org/10.1016/j.antiviral.2018.05.001.
66. Xia S, Yan L. A pan-coronavirus fusion inhibitor targeting the HR1 domain of human coronavirus spike. 2019;5(4):eaav4580. https://doi.org/10.1126/sciadv.aav4580.

67. Lu L, Liu Q, Zhu Y, Chan KH, Qin L, Li Y, et al. Structurebased discovery of Middle East respiratory syndrome coronavirus fusion inhibitor. Nat Commun. 2014;5:3067. https://doi.org/ 10.1038/ncomms4067.

Publisher's Note Springer Nature remains neutral with regard to jurisdictional claims in published maps and institutional affiliations. 